\title{
Song Texts for Entertainment
}

\section{Methodological Issues Concerning the Collection of Song Texts}

The song texts in this Appendix 4 consist mostly of four-line verses (susualan or sisindiran) for entertainment and were discussed in Chapter 7. Song texts of pantun stories were here excluded and treated in Section 6.5. The texts were collected in a number of ways. I ordered the texts more or less according to the time of recording the songs or notating the texts:

A. Texts of songs recorded and notated in 1976 (angklung);

B. Texts of songs recorded in October 1992 (angklung, kacapi, vocalist + kacapi + rendo);

C. Song texts recorded and notated in 2003 (vocalist + kacapi siter + viol);

D. Susualan notated from reciting the poems, not performed in singing, in 2003: 2003-12 Collection Ina from Pal Opat (16 susualan stanzas);

2003-13 Collection Kaduketug (14 susualan stanzas);

2003-14 Collection Hamdan (4 susualan stanzas);

2003-15 Collection Cibéo (10 susualan stanzas).

In 2003 I made a special effort to get song texts of a better quality, because transcribing from a recording, as I did for most 1992 recordings, is not always very reliable. Most of the texts presented in this Appendix 4 date from 2003.

When recording in and around Kanékés in June and July 1976, I did not manage to write down any song text, although I had recorded singing, for instance with the keromong in Gajéboh. Only in September 1976 I managed to obtain texts of six songs sung with the angklung ensemble. With the information supplied by the Baduy players these texts were written down in Sundanese by Uk Sukaya, ${ }^{1}$ during and immediately after the performance in the garden of our house near Pasar Rumput, Manggarai in Jakarta, around midnight 8-9 September 1976 (tape B15, items 1-5, and B16, item 1). These angklung song texts were slightly corrected by the Baduy village secretary Sapin in 2003. During their playing the angklung players walk around in a circle. The solo singer is not playing an instrument as well, but I did not make enough efforts to record his singing of the texts properly. Anyway, the presented texts are only approximations of what is actually to be heard on the angklung recordings. It is clear that the singing

1 Uk Sukaya assisted me in the fieldwork with the Baduy in June and July 1976; see also Appendix 3 . 
in the recordings is much longer than the presented texts in Section A of Appendix 4. The main reason is that in the performed text some lines and whole stanzas are being repeated.

During my 1992 fieldwork only a limited number of song texts were written down. The angklung texts in Section B of this Appendix were written down by Enip Sukanda, who assisted me at that time, immediately after the recording. Again, these texts are only a part of what was actually performed. In 1992 I pushed the kacapi player Sawari to sing with his own kacapi accompaniment. Until then I had only recorded kacapi players that performed instrumentally, but I knew that they could also sing, because they performed pantun stories (for instance, the players Sajin, Sawari and Yanci). Hence Sawari sang two songs (Piit Mandi, and BudakBagus) to his own kacapi accompaniment. He used a falsetto voice and the texts were immediately written down. I reported on this with a music transcription of the vocal part of Piit Mandi in Van Zanten (1995: 530-531, 541). From the recording of Budak Bagus ( $\left.<\mathrm{AV}_{31}>\right)$ it is clear that Sawari repeats parts of the text and adds a few words.

In October 1992 I also recorded the vocalist Raidah, who was then accompanied by the kacapi player Yanci and the rendo player Darmin, who later became jaro pamaréntah Daénah (1997-2015). I did not have the opportunity to write down the texts of the songs at the time of recording. Only later I transcribed some texts from these recordings and published a few results in Van Zanten (1995: 531-532, 542-543). As I recorded Raidah again and obtained more reliable texts of her songs in 2003, I concentrated on these 2003 texts and only included a few of the 1992 texts in this Appendix 4.

In 2003 I tried to get more, and more reliable, song texts. I recorded the vocalist Raidah again with the accompaniment of her husband Arib playing the viol/biola and Satra (Satrawinata) playing a flat kacapi siter. My assistant Mumu Zaénal Mutaqin transcribed the texts from the recordings and we discussed the notated song texts with Raidah, Arib and Mumu a few days after the recordings and after these had first been checked with others, including the kacapi player Satra. Most of the 2003 texts are from Raidah's eleven songs discussed in Section 7.3: Kidung Rahayu, Tepang Sono, Daun Hiris, Jalan, Gunjaér Mundur, Kacang Asin, Bayu-Bayu, Poho Kabalik, Kapergok, Daun Puspa, and Ucing-Ucingan. This set of songs contains about seventy susualan stanzas. From this collection it becomes clear that certain lines or stanzas are repeated in a particular song, or used in other songs. I did not try to find out which susualan are unique for the Baduy. I suppose that many of the texts presented here are also known in the larger Sundanese area.

Sapin, in 2003 the de facto secretary of Kanékés village, corrected the texts that I had collected and notated before (roughly the texts now to be found in parts A and B). Sapin also wrote down sixteen 4-line stanzas (susualan) that were recited by Mrs Ina of Baduy descent and living near his house in Pal Opat, Leuwidamar (included in '200312 Collection Ina from Pal Opat'). At that time Mrs Ina also recited a stanza from Cibéo 
that was meant to cast a spell on someone (pélét) in order to arouse love. Sapin refused to write down this stanza and it is not in this collection. A few days later Sapin also notated fourteen susualan recited by boys at the house of jaro pamaréntah Daénah in Kaduketug, which are included in the '2003-13 Collection Kaduketug' below.

In April 2003 I asked the musician Hamdan/Aki Armad from Kadujangkung, whether he could sing while playing his kacapi siter. He said that he could not combine the two and he started singing a susualan without zither accompaniment. He repeated this by reciting/half singing and my assistant Mumu wrote down the four susualan, which may be found in the '2003-14 Collection Hamdan' below. Similarly, this happened with the ten susualan we collected from an Inner Baduy living in Cibéo (possibly Karamaén): these were recited and notated by Mumu and are to be found in the ‘2003-15 Collection Cibéo' below.

\section{A Song Texts Notated in 1976}

1976-o1 Ngasuh

(angklung, B15 \#1, 1976)

1. Bubuay pucuk kacapi,

Nilas awi nu muranténg

Bubuhan budak lalaki,

Acan kawin geus paréréndéng ${ }^{2}$

2. Sok hayang ka gula lima

Sakojor di kaparakeun

Sok hayang ka urang dinya,

Ngagojod ngararasakeun

3. Nguseup bogo meunang paray, $^{3}$

Angin barat katimurkeun

Mun bogoh ulah katara,

Kudu bisa nyalimurkeun

4. Ngala humbut ngala jantung,

\section{To take care}

The rotan blossoms, the sprouting of the kacapi tree

The bamboo that hangs over is cut off. The group of boys,

Not yet married, already sitting close to the girls.

Often I want to go to the five pieces of sugar Being put together in one packet of ten pieces Often I want to go to the person over there To lie under a blanket and feel [her].

Fishing bogo fish and catching paray fish

The wind from the west is veering round to the east

When you are in love, do not show this You should be able to disguise it.

Get the young palm sprouts, get the banana blossom

2 In version by Uk Sukaya: paparéndéng.

3 In version by Uk Sukaya: leng kapara. 
Ngala owér di kojaan

Hayang imut ka nu jangkung,

Hayang noél ngabogaan.

1976-o2 Ayun-Ayunan

(angklung, $\mathrm{B}_{15}{ }^{\# 2}$, 1976)

1. Mulung limus meunang malang,

Digarogot di beutina

Hayang imut jeung kahayang,

Dasar bogoh ti tadina

2. Meuyeum ganas dina eurih,

Di jalan ka Cikoléar

Beuteung kami panas peurih,

Dilalar teu disaréan

3. Cai mulang, cai malik,

Muhara ka Ciangsana

Hayang mulang hayang balik,

Ngumbara kieu rasana

1976-o3 Kokoloyoran

(angklung, B15\#3, 1976)

1. Sok hayang ka gula lima,

Sakojor di kaparakeun

Sok hayang ka urang dinya,

Ngagojod ngararasakeun

2. Mulung binglu rag-rag

kembang,

Sahulu rag-rag ka situ

Mun rék ilu ulah semang,

Mun daék buburuh nutu ${ }^{5}$
Get the banana blossom in the plaited bag

I want to smile at the tall one

I want to touch and to possess her/him.

\section{Rocking}

I picked up the mango, I got the policeman of the village

I munched it to the stone

I want to smile and I have a desire

I am really in love, for some time already

To let pineapple ferment in the tall grass

On the road to Cikoléar

My stomach feels hot and painful

People passed and nobody slept in my house.

The water runs back, the water returns

To the estuary at Ciangsana

I want to go home, I want to go back

And live with my wife, ${ }^{4}$ that's what I feel

\section{To roam about}

[ = stanza 2 of song Ngasuh; see there]

I pick up a mango, flowers fall

One falls over there

If you want to take part, do not be afraid

If you want to do the work of rice pounding

4 Eringa (1984) gives for ngumbara: 'temporarily staying in a foreign region (for work, study)', however, I was told that the Baduy also use ngumbara for: 'following your wife, going to where she is living' (A2003-1: 23).

5 Uk Sukaya wrote 'mutu', but in 2003 Sapin suggested it should be 'nutu' from tutu (pounding). 
3. Awi wulung cangkilungan, Saruas dipaké miruha [mirua?] [Nu burung siling kilungan?], Pantes gé da saruana

\section{6-o4 Randa Ngéndong}

(angklung, B15 $5_{4}$, 1976)

1. Peuteuy leubeut raranggeuyan,

Di jalan ka huma jauh

Meungpeung deukeut

wawageuyan,

Jaga mah urang pajauh

2. Ngundeur hiris sabubugan,

Di jarami ketan hideung

$\mathrm{Nu}$ geulis gugurubugan,

Nyeueung kami kuru hideung

3. Ngala suluh ngala daun,

Ngala piturubeun panjang

Henteu tulus ka nu jauh,

Hayang seubeuh ${ }^{6}$ budak lanjang

4. Ka hilir ka girang deui,

Kaburuan ki nangkoda

Teu isin teu wirang teuing,

Timburuan karoronda ${ }^{7}$

\section{6-05 Pileuleuyan}

(angklung, $\mathrm{B}_{15}{ }^{5}$, 1976)

1. Hayang udud daun kawung,

Teu kawasa ngabakoan
The dark bamboo is affected by beetles A piece of bamboo is used to make fire Yes, I will support you without further questions That is understandable and makes no difference.

\section{The widow stayed for the night}

The petai bean tree is full of strings of fruit

The road to the rice field is long

We are together, so let's be happy,

Later we will be far away from each other

Collecting many beans

In the field with stubbles of black glutinous rice

The beautiful girl startles every time

When she sees that I am thin and black

Get firewood, get leaves,

Get the cover for the rice pot

I do not go to the ones far away

I want to enjoy myself with the girls

Going downstream and upstream again

The skipper is in a hurry

Do not be ashamed, do not be abashed too much

To be jealous when we sing in turns

\section{Farewell}

I want to smoke a cigaret made of the sugar palm leaf

I have no means to smoke tobacco

6 Literally: 'get saturated'.

7 Van Hoëvell (1845:424) gave a very similar susualan stanza that runs, in his Sundanese spelling: Ka hilir ka girang deuhi, Kembang peuteuï raranggeü̈an; To isin to wirang deuhi, Bareng peuting rereudjeungan. He translated this as: 'Going down as well as going up, the peuteuy/ petai flowers are sprouting; do not be shy and ashamed, because we shall meet tonight.' 
Hayang ilu jeung nu jangkung, I want to follow the tall one

Teu kawasa ngadagoan

I can no longer wait

2. Susukan jalan Cileungcang, The irrigation stream along the road to Cileungcang

Di péngkong di kakolongkeun Is dammed up and there is a hole dug under it

Isukan kami neuk leumpang, Tomorrow we shall go

Pacuan ngaroromongkeun Don't speak ill of us.

3. Teu kukup naék kalapa,

I cannot climb a coconut tree

Teu ka wawa ku leueurna

I am not able to do so, because it is slippery

Teu kukup daék ka randa,

Teu ka wawa ku heureuyna

I am not in a position to want to go to the widow

I cannot do so, because she teases me

1976-o6 Ceuk Arileu

People say that there are many bends in the river

(angklung, B16\#1, 1976)

1. Cai mulang, cai malik,

Muhara ka Ciangsana

[= stanza 3 of song Ayun-Ayunan; see there]

Hayang mulang hayang balik,

Ngumbara kieu rasana

2. Jamang hideung dikancingan, The black shirt is supplied with buttons

Di kancingan ku rajasa Furnished with buttons of tin

Budak hideung mantak nineung, The black boy, because of his desires

Ti peuting teu ngeunah rasa

During the night he has no pleasant feelings

3. Nguseup bogo meunang paray, [= stanza 3 of song Ngasuh; see there]

Angin barat katimurkeun

Mun bogoh ulah katara,

Kudu bisa nyalimurkeun

\section{B Texts of Songs Recorded in October 1992}

1992-o1 Ceuk Arileu

(angklung, DAT 92-7, A1992-1: 42)

1. Ceuk arileu, ceuk arileu (2x)

Samping poléng kahujanan

Ceuk ka dieu, ceuk ka dieu

Kami goréng kaédanan
People say that there are many bends in the road

People say that there are many bends in the road The woven checkered sarong has become wet by the rain

Sister, come here, sister, come here

I am really crazy about you 
2. Kacapi ukir-ukiran ${ }^{8}$

Tangkal salak jatakéan

Lalaki euweuh pikiran

Gancang nolak teu makéan

1992-02 Oyong-Oyong Bangkong

(angklung, DAT 92-7, A1992-1: 42)

1. Oyong-oyong bangkong

Ka cai teu dimandikeun

Omong-omong bohong

Ku naon teu dijadikeun

2. Hayang teuing geura beurang

Geus beurang ka panyacaran

Hayang teuing geura beunang

Geus beunang teu panasaran

1992-o3 Oray-Orayan

(angklung DAT 92-7, A1992-1: 42)

1. Oray welang oray hideung

Oray sanca digawingkeun

Ulah melang ulah nineung

Poé Salasa dikawinkeun
The zither is ornamented with woodcarvings

The salak bush and the gandaria bush

The man who does not think

Easily ends the marriage - do not take him.

\section{The frogs swim to their hearts' content}

The frogs swim to their hearts' content

At the river they do not bathe

Many lies are told

Why did it not happen?

My desire is great, it will soon be noon

When it is noon we will go to the field that is cleared from bushes

My desire is great, I want to have it soon

When I have it, I shall be satisfied

To move like a snake ${ }^{9}$

The very poisonous snake, and the black snake The python is suspending

Do not be anxious, do not be eager

On Tuesday you will be married

\section{Title unknown (1992)}

[The following stanza was not sung, only the text was recited. It consists of three lines and it may not be complete. It was said (A1992-1: 30) that the singer of this stanza hopes that the person to whom it is directed will understand this as a sign of her/his love to him/her.]

8 According to Sapin: 'untir-untiran'; this word is not in the dictionaries Coolsma (1884), KU BS (1976) and Eringa (1984). Sapin is supported by the fact that Baduy kacapi zithers made in Kanékés are never ornamented with woodcarvings, but made of plain white lamé wood; see also Section 7.4. Stevens and Smidgall-Tellings (2010) give untir (Javanese) to be the same as puntir, 'plaited, twisted'; Eringa (1984) gives for puntir 'turning around'. The translation for kacapi untir-untiran could then be: 'the zither is turning around.'

9 Oray-orayan is a children's' game in which 'the participants walk after each other, while keeping their hands; the first one tries to catch the last one' in the row (Eringa 1984). 
Seura siuh hujan ti jauh

Seura séah hujan silantang

Sora kumbang di sagara

1992-04 Piit Mandi

(male voice of Sawari + kacapi, DAT 92-7, A1992-1: 33)

Piit mandi jeung dadali Manuk hurang ${ }^{10}$ kagirangkeun Hayang balik diiringkeun Hayang pulang kawiwirangan

\section{2-05 Budak Bagus}

(Male voice of Sawari + kacapi, DAT 92-7, 38:50-41:45, A1992-1: 34. Performed text is more elaborate, but difficult to understand.)

Ngala suluh kayu hirup Pancer paéh dipotongan Hayang ilu saumur hirup Kalah paéh jeung popotongan 1992-06 Kembang Beureum

(Vocalist Raidah with rendo and kacapi accompaniment, DAT 9214, 14'40"-16'35", 8 Nov. 1992)

1. Kembang beureum nu babeureum [2x]

Harép jambu médena [2x] Kieu meureun, kitu meureun [2x] Lalajo jeung bébénéna [2x]
The rustling sound of the rain far away The swishing sound of the rain that falls over there

The sound of the bumble bee is everywhere ('in the ocean')

\section{The piit bird takes a bath}

The ricebird takes a bath and the eagle The shrimpbird goes upstream I want to go home and be escorted I want to go home because I have been made ashamed

\section{The handsome boy}

I fetch firewood, still alive on the trees

The root will die when it is cut

I want to accompany you during my whole life

To defeat death and divorce

Redflower(s)

Red flowers in several shades of red

I would like to have jambu monyet fruit

Whatever the situation

I shall look for my fiancée

10 In Van Zanten (1995: 541) I wrote manuk kurang, however, from the recorded discussion on DAT $92-7$ it is clear that it should be manuk hurang, the 'shrimp bird' that catches small fish from the streams (KUBS 1976). 


\section{Kembang laja}

Kembang bonténg di astana

Kaniaya ngumbara

$\mathrm{Nu}$ awon kieu rasana

3. Kumaha mayu [nu?] manahna

Sampé nulén kahujanan

Kumaha nu manahna

Sangkan ulah kaédanan

1992-o7 Néng Gaya

(Vocalist Raidah, DAT 92-14, 17'20"-

20'16", 8 November 1992)

1. Nu engkang gaya, abdi gé gaya

Duh, sarua mah, sarua pada gayana

Nu engkang jempol, abdi gé jempol

Deudeuh sarua mah, sarua pada jempolna

2. Nu engkang aksi, abdi gé aksi

Deudeuh sarua mah, sarua pada aksina

Tukang kendang gaya, euh, abdi gé gaya

Deudeuh sarua mah, sarua pada gayana

3. Tukang kacapi gaya, euh, abdi gé gaya

Deudeuh sarua mah, sarua ngiringan gaya

Tukang rendo jempol, abdi ogé ngiring jempol

Deudeuh sarua mah, sarua ngiringan jempol
The laja flower [used as a herb]

The cucumber flower at the grave

Ill-treatment will come

Bad things give these feelings

How about the heart?

Which became really wet by the rain [?]

How about the heart?

I hope that it will not hopelessly fall in love

\section{Girlwith style}

The style of living of my elder brother, I also have a style of living

$\mathrm{Oh}$, it is exactly the same, it is the same style of living

If my elder brother is good, I am also good

My dearest, it is exactly the same, the same goodness

The way of acting of my elder brother, I also have a way of acting

My dearest, it is exactly the same, the same way of acting

The drum player has a style of playing, oh!, I also have a style

My dearest, it is exactly the same, the same style of playing

The zither player has a style of playing, oh!, I also have a style

My dearest, it is exactly the same, we follow the same style

The bowed lute player is very good, 1 am also very good

My dearest, it is exactly the same, we are all very good 
1992-11 Turun Daun

(Vocalist Raidah, DAT 92-14, $\mathrm{h}$

1'25" - 1h 4'18", 1992, accompanied

by Yanci on kacapi and Darmin on

rendo

1. Sarikaya kembang laja

Kembang bonténg di astana [2x]

$\mathrm{Nu}$ kaniaya (2x) ngumbara

$\mathrm{Nu}$ awon kieu rasana ${ }^{11}$

2. Kumaha (mah) (2x)

mulunganana

Sangkan urang kahujanan

Kumaha (mah) (2x) na mayungan

Sangkan ulah kaédanan

3. Balimbing(na) (2x) jadi di pipir

Paré peuteuy ku badori

Abdi moal (2x) tiis pikir

Mun tacan (mah) (2x) laksana diri As regards not yet accomplishing my wish

4. Kuring (mah) (2x) dina babantu I am assisting others

Melak bonténg di basisir

Mipalay sanés kitu

Abdi moal tiis pikir

\section{Falling leaves}

Sarikaya/sirikaya fruit and flower of the laja bush

The cucumber flower in the graveyard

Ill-treatment will come

Bad things cause these feelings

How do we pick up and collect things

When we have become wet by the rain?

How can we protect [ourselves] with an

Do not get mad in love

The balimbing fruit grows at the side

Rice, peuteuy beans and badori shrub

I am not quiet

To plant cucumber at the beach

Do not desire that woman

I am not without troubles umbrella?

\section{C $\quad$ Song Texts Recorded and Notated in 2003}

\section{3-o1 Kidung Rahayu}

(Vocalist Raidah, MD 2003-

o8,15:47-21:40, recorded 26 March

2003. Accompaniment: kacapi

siter by Satra and viol by Arib)

1. Bismilah ngawitan kidung In the name of God we start [the song] Kidung

11 This stanza is very similar to Kembang Beureum, stanza 2, and Apa Roda, stanza 2, also sung by Raidah in 1992. 
Abdi nye (m)bat asma Gusti (2x) I call the name of God

Kidungna kidung rahayu

The [song] Kidung [means] singing about prosperity

Rahayu (mah) nu maha suci [soci] Prosperity that is very holy

2. Bul kukus ngelun ka manggung The burning incense rises into the air

Nyambuang (mah) ka awang- It rises and spreads in the air awang $(2 \mathrm{x})$

Di luhur sausut rambut

Above the edge of the hair

Di handap sausap dampal

Below the sole of the feet

Di tengah mah puseran [puteran?] In the middle the great navel ageung

3. Nu ti kidul nu ti kalér

Di tepis ngiring basisir

$\mathrm{Nu}$ ti kulon nu ti wétan

Suku gunung lamping pasir

Nu ngagegek panca tengah

Apa lurah apan kenal di sadayana

Putra putri Siliwangi

4. Nya ingsung bayu rahayu

Bayu mulus bayu asih

Bayu sajatining manik

Ngadiri alam kiwari

Ngajajah alam ayeuna $(2 \mathrm{x})$

5. Neda agung sampura sun

Ka Gusti nu welas asih

Nyanggakeun mah sadaya-daya

Nyanggakeun ti kabodoan

Sima abdi (mah) sapara kanca

Amin ya Robal alamin

Ka Gusti nantayungan

2003-02 Tepang Sono

(Vocalist Raidah, MD 2003-08,

22:06-28:42, recorded 26 March

2003. Accompaniment: kacapi

siter by Satra and viol by Arib)
Those from the south and from the north

[Are] along the beach

Those from the west and east

[Are] at the foot of the mountain, at the slope of the hill

Those who live in great numbers in the middle

Sure Mr. villagehead, it is known by all,

[Are] the children of Siliwangi

I am the wind of prosperity

The prosperous wind, the wind of love

The wind that is really precious

It is in the present world

It lives in the world today

Respectfully we beg forgiveness

From God who is full of mercy

We respectfully give you all this.

We present it, although we are ignorant,

I and my friends.

Amen to God, Amen

To the allmighty God

\section{Affectionate meeting}


1. Jungjunan ari ngahaturkeun Ieu lagu Patepang Sono

Patepang mah di panggung seni (2x) $\mathrm{Nu}$ manis

Bilih abdi, bilih abdi da kirang sono

2. Nyanggakeun mah silaturahmi (2x)

Ieu lagu Tepang Sono

$\mathrm{Ku}$ abdi mah patepang di

alun-alun

Bilih abdi kirang sono

Pamugi keursa ngamalum
Highly honoured one(s), I present you

This song 'Affectionate Meeting'

We meet at the stage for the arts

Which is pleasant

It is possible that I am less affectionate

I give you a bond of friendship

[Through] this song 'Affectionate Meeting'

Meet with me at the town square

It is possible that I am less affectionate

I hope that you will forgive me

3. Mangga urang hayu sasarengan, Let us be together, highly honoured one(s), jungjunan

Majengkeun mah seni kagungan

Seni Sunda tuturunan apan

Warisan karuhun urang

Let us practise ${ }^{12}$ the arts that we have

The Sundanese arts from previous generations

The heritage of our ancestors

4. Jungjunan ari ngahaturkeun

Ieu lagu Patepang Sono

Patepang mah sareng sim abdi

(2x)

$\mathrm{Nu}$ manis ieu lagu Patepang Sono

Highly honoured one(s), I present you

This song 'Affectionate Meeting'

Experience together with me

The sweetness of this song 'Affectionate

Meeting'

[whole stanza repeated]

5. Patepang mah di parapatan (2x) We meet at the crossroad

Kumaha dicarék nyangéjo

How can you forbid to steam the rice?

Da puguh mah jungjunan

bangbara hérang

As you know, honoured one, the bumblebee is

Kumaha mah dikaréh sono

Da puguh abdi téh melang

6. Ieu lagu Tepang Sono apa

Patepang mah sareng sim abdi

Nyanggakeun mah ti kabodoan

bright

How do we stir [bring about?] affection?

I am concerned about this.

This is the song 'Affectionate Meeting'

Meet with me

And receive it in humbleness

12 Literally: develop 
Sim abdi sapara kanca

7. Jungjunan ari ieu lagu Patepang Sono

Patepang mah di panggung seni (2x)

$\mathrm{Nu}$ manis ari ngahaturkeun Ieu lagu Patepang Sono

8. Patepang mah di parapatan $(2 \mathrm{x})$ We meet at the cross-road Jungjunan bilih abdi ka kirang sono

Pamugi mah keursa ngamalum Ka abdi sapara kanca

2003-03 Daun Hiris

(Vocalist Raidah, MD 2003-08, 29:53-35:43, recorded 26 March 2003. Accompaniment: kacapi siter by Satra and viol by Arib)

1. Teuteup deudeuh moal burung dipisono

Haté kuring moal beunang dibobodo

Daun hiris saksina nu ngémploh héjo

Atuh panutan diantosan ti baréto

2. Daun hiris kembangna

kumbyang koronéng

Kaéndahan ayana di sisi émpang

Panutan émut basa kuring anténg nyawang

Duh waktu mitineung haté jadi honcéwang
[From] me and my companions

\section{Meeting'}

Let us find it at the stage for the arts

This sweetness, I present

This song 'Affectionate Meeting'

Honoured one(s), possibly I will be less

affectionate

I hope that you will forgive me

Me and my companions

Leaves of the hiris plant ${ }^{13}$
Oh, my love, let it not happen that we do no longer care about each other My heart cannot be mislead

The fresh and green hiris leaves are witnesses

Oh, my love, I have been waiting for a long time

The hiris leaves and its yellow flowers

Their beauty can be seen at the side of the fishpond

My love, remember when I was quietly at home and contemplating When thinking about you, my heart became troubled.

13 Leguminous plant 
3. Ngabibita daun hiris sisi gawir I am jealous of the hiris leaves at the edge of the ravine

Aduh ampun, takbir teu beunang Oh, fate cannot be avoided dipungkir

Beurang peuting abdi teu weléh Day and night I incessantly try

ihtiar

Geuningan sulaya panutan

But you do not care at all

tambélar

4. Buktina ngaraheutan

Look, I have been wounded for a long time sapanjangna

Pupuasan naon pilandongeunana

Mingkin lami badan téh tambah

Which medicine can cure this? tunggara

Aduh ampun seueur pisan

The longer it lasts, the deeper my sorrow

gogodaanana

[repeat of stanzas 1, 2 and 3]

2003-04Jalan

The road/to travel

(Vocalist Raidah, MD 2003-08, 47:29-55:53, recorded 26 March 2003. Accompaniment: kacapi siter by Satra and viol by Arib)

1. Turiang mah turiang dina

Shoots of rice between the stones

babatu

Turiang dina babatu

Apa lurah anu bageur

Oh, there are so many temptations!

Melak pandan di basisir

Mikapalay sanes kitu

Matak jadi gering pikir

2. Mangandeuh keur

karembangan

Renggangna urang petikan

Mikadeudeuh mikahéman

Mr. village head you are nice ${ }^{14}$

To plant pandan bushes on the beach

Do not desire that woman

It will make you ill because of thinking [about her]

The parasitic plants are flowering

They stand alone and we pick them

To love each other, to care for each other with love

14 The performance took place at the house of the head (jaro pamaréntah) of Kanékés, Daénah; he was present during the performance. 
Paanggang mah paanggang silih antosan

3. Di basisir loba layu (2x)

Pa Haji Sapin anu sayang

Diala ku nu dibuat

Pikir abdi keur tagiwur

Sok asa kasuat-suat

4. Pongporang di luhur gunung

Saung di handapeunana

Abdi melang ka nu pundung

Kumaha (2x) néanganana?

5. Peupeujeuh (2x) mah gunung kabitur

Peupeujeuh gunung kabitur, apa Mésér kupat dibabonan

Peupeujeuh abdi rék wangsul

Ulah ngupat (2x) kaawonan

6. Kikinciran-kikinciran sihoréng (2x)

[Obat kabeuleum

dipikiran-dipikiran?]

Sing horéng mah sing horéng

Sobat kadeungeun

7. Kanikir mah kanikir

Jeung kembang gambir

Kanikir jeung kembang gambir

Jungjunan, tangkal honjé jeung

kanyéré

Dipikir beki kapikir

Horéng mantak $(2 x)$ rajét haté
Far apart we wait for each other

Near the beach are many layu fishes

Mr. Haji Sapin we like you ${ }^{15}$

It is taken by the one who did it [caught the fish?]

My thinking is chaotic

Sad memories fill my mind

The pongporang tree high up the mountain

The shelter that stands below it

I am worried about the angry person

How shall I face him?

Mind the mountain that becomes visible

Mind the mountain that becomes visible, sir

To buy many packs of cooked rice

Mind me, I want to go home

Do not pack bad things

The propellers, well, well!

It is thought that the medicine was burnt

Well, well,

My friend has become a stranger

[compare Ucing-Ucingan, stanza 10]

The kanikir plant ${ }^{16}$

And the gambir flower

Kanikir and gambir flower

My lord, the honjé and kanyéré trees

I am worrying all the time

This causes my heart to break

15 Haji Sapin was present at the performance. He is a former Baduy who migrated and became Muslim. Sapin was assistant-secretary of the village head from 1993-2007 and became secretary (carik) from 2007-July 2016.

16 Kanikir or ulam raja is a plant of which the leaves may be eaten. 
8. Kumaha disada heulang

Ngelik-ngelik dina jati (2x)

Kumaha mah rasa nu melang

Ceurik sajéroning ati ieu

9. Seureuh sama seureuh mah

Sagulung dijalan-jalan apa

Ditéang kantun talina

Urut sagulung-sagalang
How is the cry of the heulang bird of prey?

'Èh, èh' in the jati trees

What about my anxious feelings?

My heart is weeping

[see also Gunjaer 9]

Sirih leaves and [more] sirih leaves

One roll is lost, sir

You see the remaining string

In ealier times together

Ayeuna mah ayeuna kantun nyérina Now sadness remains

10. Rék ngala iwung ka huma

Kadé bisi awi surat

Bisa nulung ka sasama

Mun salah mah silih hampura

11. Ti batan mah ti batan saélo lébar $(2 \mathrm{x})$

Sekajuh didambel kayu

Ti batan jalmi nu sabar

Tinangtos mah mulus rahayu

2003-05 Gunjaér Mundur

(Vocalist Raidah, MD 2003-08, 63:07-70:19, recorded 26 March 2003. Accompaniment: kacapi siter by Satra and viol by Arib)

1. Jungjunan bujaér mundur Mundurna mah ka alun-alun Ulah waka ala lundur Pamugi keursa ngamalum

2. Duh ieuh mujair mundur Mundurna mah ka solokan Ieu bapa tong waka mundur Sim kuring badé ngantosan 3. Awi belang awi hideung17 Dipulas mah dina lomari
I want to take the small bamboo plants to the huma field

Be careful, it could be surat bamboo You can help each other

In case of a mistake, forgive each other

When it has the width of a yard

A cashew tree is made into wood

When a person is patient

Surely she/he will become prosperous

The gunjaér fish retreats

My lord, the bujaér fish retreats

It retreats to the village square

Do not yet go home

I hope that you will forgive me

Well, the mujair fish retreats

He retreats to the small canal

Do not yet go home, sir

I want to wait

Spotted bamboo, black bamboo

It has been painted and lies in the cupboard

17 Compare a similar stanza in Van Hoëvell (1845: 414) 
Kami melang kami nineung

Saé sumping ka sim abdi

4. Angka dua angka tilu

Dikuras mah dina lomari deui

Badé didua badé ditilu

Mangga waé asal ulah dinyenyeri

5. Tong tulus nanjak ka huma

Bilihna mah manggih sumamun

Kedah saé ka sasama

Budi manis saé semu

6. Ka mana ngaitkeun kincir

Ka kalér katujuh bulan

Ka mana niiskeun pikir apa

Moal palér ku sabulan

7. Ka mana marénta payung

Sakieu panas poéna

Ka mana marénta tulung

[pulung?]

Sakieu panas haténa

8. Ka mana mayunganana

Sangkan ulah kahujanan

Ku naon nulunganana apa

Sangkan ulah kaédanan

9. Kumaha disada heulang [...]

10. Ka mana jalan ka Cibuluh

Mun nanjak ka Cimandiri

Ka saha abdi nyaluuh [ieuh]

Mun mendak tunggara diri

11. Ka Baros jalan ka Lembang

Mésér bensin di kaléngan

Sanaos tacan kasorang

Batin tetep sasarengan

12. Manuk piit jeung kapinis

Di lebah keur nyaratuan
I am worried, I am thinking about and longing for you

It would be nice if you came to me

The cipher two, the cipher three

Are again cleaned out in the cupboard

You want to be with two, or with three?

Go ahead, as long as it does not harm

Do not go up the hill to the rice field

You may be very lonely there

It must be good to be together

If you behave well, it will turn out to be so

Where to hook up the spinning wheel?

To the north, the seventh month

How shall I become quiet, sir?

Let it not disappear within a month

Where do I ask for an umbrella?

It is so hot today!

Where do I ask for help?

My heart is so disturbed!

Where should we place the umbrella?

Let it not start raining

Why do I ask for help, sir?

Let it not come to madness

[=Jalan, stanza 8: see there]

Where goes the road to Cibuluh

If you go uphill to Cimandiri?

To whom do I go

When I am in distress?

To Baros, the road to Lembang

To buy petrol in a tin

Although I am not yet struck with sorrow

[If so] my spirit will stay with him

The piit and the kapinis birds

They are eating in the valley 
Sapapait samamanis Apa

$\mathrm{Nu}$ disebat persatuan

13. Kumaha mayunganana

Sangkan ulah kahujanan

Kumaha nulunganana

Sangkan ulah kaéndahan

2003-o6 Kacang Asin

(Vocalist Raidah, MD 2003-09, 10:05-16:43, recorded 26 March 2003. Accompaniment: kacapi siter by Satra and viol by Arib)

1. Ari kacang kacang asin

Asinna mah diuyahan

Abdi isin abdi isin

Isinna (mah isinna) ka nu duaan

2. Ari kacang kacang asin

Asinna mah diuyahan

Abdi isin abdi isin (geuningan)

Isinna ka nu duaan

3. Ari kacang kacang asin

Asinna dibeungkeutan

Abdi isin abdi isin

Isinna (mah isinna) ku

dideukeutan

4. Sarikaya kembang laja

Kembang sangkéng di astana

Kaniaya nu tunggara ieuh

$\mathrm{Nu}$ awon kieu rasana

5. = Jalan, stanza 10

6. = Gunjaér Mundur, stanza 10

7. = Kacang Asin, stanza 1

8. = Kacang Asin, stanza 3, except

line 4: without "isinna ku"
Sorrow and sweetness, sir

Will go together

What about the umbrella?

Let it not start raining

What about asking for help?

Let it not come to madness

[Compare stanza 8: almost the same]

Salted peanuts

Peanuts, salted peanuts

The salt is added

I am ashamed

The shame concerns the two of us

Peanuts, salted peanuts

The salt is added

I am ashamed

The shame concerns the two of us

Peanuts, salted peanuts

The salt is put to it

I am ashamed

The shame is because we were close together

The sarikaya fruit and laja flower

The sangkéng flower in the graveyard

Ill-treatment [of] those in great distress

Bad things cause these feelings

[Compare Turun Daun, stanza 1 and Apa Roda, stanza 2] 
9. = Jalan, stanza 4

10. = Gunjaér Mundur, stanza 6,

except line 3: "Ka mana mah mun

niiskeun pikir"

11. = Jalan, stanza 1

2003-o7 Bayu-Bayu

(Vocalist Raidah, MD 2003-o9,

18:51-24:33, recorded 26 March

2003. Accompaniment: kacapi

siter by Satra and viol by Arib)

1. Mun urang nyaho ka diri

Sugan moal (2x) iri dengki

Moal loba suka sering

Ngumbara di alam mulki ${ }^{18}$

Mulki téh béjana dunya

2. Nu peuting nandingan beurang

Lamun urang sing karunya dulur

Ka sasama nu teu terang

Béjaan geura béjaan

Ulah sok papaséaan

Mun puji urang enyaan

Kantos miceun kasatoan ${ }^{20}$

3. Hirup katungkul ku pati

Maot teu terang dimangsa

Badan gé nya kitu kénéh

Aya pangbalikanana

4. Sanajan sarébu betah

Moal megar cara oray

Di dunya moal arék mutuh

geuraan

\section{Breaths of Life/God of the Wind}

If we know about ourselves

Let us hope that we are not jealous

Let us not want much and often

We temporarily live in this world as strangers

'Mulki' means 'world'

The morning defeats the night ${ }^{19}$

When we love our brothers

Also those we do not know

Let it be known speedily

Let it not become a fight

If we really want to praise [tapa]

Renounce living like an animal, leave it behind you

Life is governed by death

Death's time is not known

That also holds for me

There is a return to the origin

Although we may feel very comfortable

We do not change our skin like a snake

In this world do not hasten to reach the ideal

state

18 The word mulki is not in Eringa (1984) or KUBS (1976).

19 Or: Light defeats darkness

$20 \quad$ Kasatoan from sato, animal, is not in Eringa (1984) and KUBS (1976). Is it sasatoan, (several kinds of) animals? 
Ngumbara tos ti balikna (2x), $\quad$ From our wanderings we return home, sir juragan

[stanzas 1, 2, 3, 4 repeated in this order]

20o3-o8 Poho Kabalik

(Vocalist Raidah, MD 2003-09, 28:17-33:47, recorded 26 March 2003. Accompaniment: kacapi siter by Satra and viol by Arib)

1. La la la la la la la, sayang Jongjon suka bungah

Siga anu betah

Bet poho ka imah

2. Najan henteu rucah

Aa bojo mah sok dipitnah

Geumpeur badan

Papanggih jeung susah

3. Naik mobil sedan

Mangkadé bilih ti balik

Ulah sok élodan

Tungtungna sok bingung balik

La la la la la la la, love

We are enjoying happiness

Like the happy people

Who forget to go home

Although she does not live licentiously

Elder brother, your wife is slandered

I am shaking

Overcome with troubles

When travelling by sedan

Be careful, it may turn upside-down

Do not get distracted

Otherwise it will cause confusion

[Stanzas 1, 2 and 3 repeated in this order]

7. La la la la la la la hadé

Seueur sindén hadé

Asa dipépéndé

Komo lamun ramé

8. Teu nolih ka capé

Poho kana gawé

Teu mikirkeun

Kariweuh ka capé

9. Naik mobil oplét

Mangkadé bilih ti balik

Ulah sok kapélét

Tungtungna sok bingung balik
La la la la la la la, good

Many (female) singers are good

It feels as if you are put to sleep

Especially when it is enjoyable

The tiredness is not felt

Work forgotten

No worrying

About being rattled by fatigue

When travelling by a small bus

Be careful, it may turn upside-down

Let not a charm of love be cast on you

Surely that will cause confusion 
10. La la la la la la la sono

Diondang lalajo

Seueur pangbébénjo

Kalah beuki sono

Najan capé ponyo

Ditunggu sang bojo [sambojo?]

2003-og Kapergok

(Female vocalist Raidah and alok

singing by Salim, MD 2003-09,

36:49-44:42, recorded 26 March

2003. Accompaniment: kacapi

siter by Satra and viol by Arib)

o. [Raidah:] Hey engkang éta

keur naon

Kasampak paduduaan (2x)

Sing horéng (mah) keur

bobogohan $(2 \mathrm{x})$

1. [Raidah starts again:] = stanza 0 repeated; [after the first line carik

Sapin shouts: 'Keur ngopi!']

2. [Salim; similar to stanza

8 ; = stanza 12 ]

Hey enéng tong sungku-sangka

Harita téh keur ngalamun

Hayang mah jadi jelema beunghar

Ulah nyangka sambarangan

Ngagedékeun timburuan
La la la la la la la, sweet memory

You are invited to watch

The many distractions

This loses from the sweet memories

[That] when you are entirely exhausted

Your wife is waiting for you

\section{Caught red-handed}

Hey, (elder) brother, what are you doing?

We happen to meet

As if we are a couple in love

Hey, brother, what are you doing?

[Sapin: 'I am drinking coffee!'] ...

Hey, girl, do not have suspicions

At that time I was imagining

That I would like to be a rich man

Do not just presume [something]

It will increase your jealousy

3. [Raidah:] Ayeuna mah engkang, Now, brother, I present you [the following] abdi serahkeun

Henteu hoyong dipangduakeun I do not want to become a couple

Buktina boro akangna téh jeung Unfortunately, there is proof that you have a awéwé $^{21}$

Engkang tos midua haté girlfriend

You already share your heart with someone

21 I am not sure about the text in this line. 
4. [Raidah; similar to stanza 10] Hey, brother, do not laugh

Hey engkang tong sungar-sengir

Ku abdi mah moal meunang You may not deny this to me

mungkir

Akang mah sok mindang langsir

Horéng aya nu ditaksir

Brother, you often switch

Truely, people watch this critically

5. [Salim; = stanza 11]

Hey, girl, do not be rude

Hey, enéng ulah calutak

Ka akang wani sesentak

You dare to snarl at me

Siga nu teu aya didikan

Like one who is not well educated

Ka akang wani nyarékan

You dare to become angry at me

Jiga ngajak pepegatan

6. [Raidah; similar to stanzas

3 and 9]

Ayeuna mah engkang abdi

serahkeun

Henteu hoyong dipangduakeun I do not want to become a couple

Enggeus bukti akang téh eujeung There is already proof that you have a girlfriend awéwé

Enggeus mungpung 22 ngadua haté You already share your heart

7. [Raidah] Hey engkang éta keur Hey, brother, what are you doing? naon?

Ku abdi téh kanyahoan

Kasampak paduaan

Si horéng keur bobogohan $(2 \mathrm{x})$
You know me already ${ }^{23}$

We happen to meet

As if we are a couple in love

[about the same as stanza 1]

8. [Salim; = stanza 2, but line 2 now: At that time I was imagining Abdi harita keur ngalamun]

9. [Raidah; = stanza 6 (lines 1,2,3); You already share your heart line 4: Engkang téh tos midua haté

10. [Raidah; = stanza 4, but line No wonder, you often switch 3: Paingan sok mindang langsir

22 Mungpung: to meet.

23 Nyaho, to know, is also used in the sense of an intimate (sexual) relation. 
11. [Salim; = stanza 5]

12. Raidah; = stanza 3]

2003-1o Daun Puspa

Puspa leaves

(Female vocalist Raidah with male

alok vocalist Salim, MD 2003-09,

49:18-55:05, recorded 26 March

2003. Accompaniment: kacapi

siter by Satra and viol by Arib)

1. [Raidah:] Lisan anjeun di Your words spoken below the puspa leaves

handapeun daun puspa

Moal poho daun nu jadi saksina

Najan layu gararing murag

kembangna

Asih kuring teu laas ku datang mangsa

2. [Raidah:] Bulan henteu

The moon did not witness the two of us

nyaksian urang duaan

Kumelang haté kabawa lamunan

Our anxious hearts were carried away by imagination

Teuteup anjeun nu seukeut ngirut Your keen eye seduced my heart jajantung

Lamun anggan matak gering

When we separate it wil cause a lingering illness ngalanglayung

3. [Raidah:] Daun puspa ngabayak The puspa leaves are scattered, with dry leaf garing régangna stalks

Deudeuh teuing kabawa ku angin My dearest love, we were carried away by the tresna wind of affection

Riceup béntang soméah The nicely blinking stars are thinking about us

mikirkeunana

Daun puspa ngajadi saksi nu pasti The puspa leaves were the witnesses, for sure

4. [Salim:] Daun puspa nu The puspa leaves that were looking after us ngiyuhan keur waktu urang duaan when we were together

Ti kawit urang papanggih

From the start, when we met

Ngajak hirup silih asih

We wanted to live [while] loving each other

Saksina ku daun puspa nu ayeuna

Witnessed by the puspa leaves that are now maruragan falling

5. [Raidah; = stanza 1] 
6. [Raidah; = stanza 2]

2003-11 Ucing-Ucingan

(Female vocalist Raidah with male alok vocalist Salim, MD 2003-09, 58:49-63:58, recorded 26 March 2003. Accompaniment: kacapi siter by Satra and viol by Arib)

1. [Raidah:] Sok hayang ucing-ucingan

Ucing belang bulu lima

Sok hayang ulin-ulinan [ieuh]

Mun melang ulah tarima [ieuh]

2. [Raidah:] Sok hayang ucing-ucingan

Ucing belang bulu tilu

Sok hayang mah ulin-ulinan

Mun melang abdi rék milu

3. [Raidah:] Sok hayang

ucing-ucingan

Ucing belang bulu dua

Sok hayang ulin-ulinan ieuh

Ulah badé pasalia

4. [Raidah:] Sok hayang

ucing-ucingan

Eunteup dina tangkal gedang

Sok hayang ulin-ulinan

Ulah sok haté salempang

5. [Salim:] Kumaha mayunganana

Sangkan ulah kahujanan

Sangkan ulah ari sangkan

Ulah kahujanan

Kumaha nulunganana

Sangkan ulah kaédanan

6. [Raidah:] Sok hayang

ucing-ucingan

\section{Children's games}

Often I want to play childrens' games

The spotted cat has five hairs

Often I want to play

When worried, do not accept it

Often ...

The spotted cat has three hairs

Often ...

When worried, I want to follow

Often ...

The spotted cat has two hairs

Often ...

Do not want to disagree

Often ...

To sit in the pawpaw tree

Often ...

Do not have an anxious heart

What about the umbrellla?

Let it not start raining

Let it not, let it

Not start raining

What about help?

Let it not come to madness

[Compare Gunjaér Mundur, stanza 8]

Often ... 
Ucing belangna buntutna

Sok hayang ulin-ulinan

Mun melang kana imutna

7. [Raidah:] Sok hayang

ucing-ucingan

Ucing gelang candramawat

Sok hayang ulin-ulinan

Mun melang sok hayang mawa

8. [Raidah:] Sok hayang

ucing-ucingan

Ucing belang bulu hiris

Sok hayang ulin-ulinan ieuh

Ulinan mah ka nu geulis

9. [Raidah:] Sok hayang

ucing-ucingan

Buntut pondok jadi panjang

Sok hayang ulin-ulinan

Urut sono jadi panjang

10. [Salim:] Kikinciran-kikinciran sihoréng $(2 \mathrm{x})$

Obat kabeuheulan ${ }^{26}$

dipikiran-dipikiran

Sing horéng mah sing horéng

Sobat kadeungeun

Dipikiran-dipikiran

Sing horéng obat kabeuheulan
The spotted cat has a tail

Often ...

When I am worried about his smiling

Often ...

The spotted cat with multi-coloured skin ${ }^{24}$

Often ...

When I am worried I want to take it [the cat $]^{25}$ along

Often ...

The spotted cat with hair like the hiris shrub

Often ...

To play with the girl

Often ...

The short tail becomes long

Often ....

Traces of love stay long

The propellors, well, well

I consider using medicine to make the process go smoothly

Well, well

My friend may become my partner

I consider

Well, using medicine to make the process go smoothly

[Compare Jalan, stanza 6]

24 Ucing candramawat, cat with multi-coloured skin, is supposed to bring fortune to its owner.

25 The cat is a symbol for a girl.

26 Kabeuleum? 


\section{Susualan Notated from Reciting the Poems, Some Performed in Singing, 2003}

2003-12 Collection Ina from

\section{Pal Opat}

[Recited by Ms Ina (and others) and notated by Sapin at his home

in Pal Opat, 21 March 2003]

1. Melak cabé sisi cai

Amis henteu lada baé

Awéwé jaman kiwari

Geulis henteu laga baé

2. Iraha urang ka Sérang

Meuli hurang jeung kapiting

Iraha urang kasorang

Reureujeungan beurang peuting

3. Duraring manuk kapudang

Duméh lain gogodohna

Nyaring ogé teu daék hudang

Duméh lain kabogohna

4. Talingtung ${ }^{27}$ talina benang

Mobil beureum diguratan

Satung-tung tacan beunang

Moal eureun disuratan

5. Piring pisin diragaji

Colénak dikalapaan

Ulah isin ka Pa Haji

Boga anak euweuh bapaan

6. Aduh ema, nyeri cinggir

Kasését ku daun awi
Plant peppers near the water

Sweetness is just not spicy

Nowadays the girls

Are sweet and do not boast

When do we go to Sérang

To buy shrimps and crabs?

When do we go

Together day and night?

The kapudang bird is humming

Because it is not a banana (for baking)

When I awake I do not want to get up

Because I do not have someone I love

The apparatus to chase the birds has a cotton cord

The red car is painted with lines

Before you have it [the girl]

Do not stop to write letters

The small plate is sawn

The colénak sweet dish contains coconut

Do not be ashamed for Mr. Haji ${ }^{28}$

[When] you have a child without a father

Oh, mother has a sore little finger

It was cut by a bamboo leaf

\footnotetext{
27 Talingtung not in Eringa (1984) or KUBS (1976); it was explained to be apparatus to chase birds in the fields, consisting of bamboo parts or empty tins hanging from a cord. 
Aduh ema, nyeri pikir

Kapélét ku nu kamari

7. Kuma suling, kuma suling

Suling téh silung baé

Kuma kuring kuma kuring

Kuring téh mung bingung baé

8. Ceuk arileu

Samping poléng kahujanan

Euceu ka dieu

Abdi goréng kaédanan

9. Kleung ${ }^{29}$ déngdék

Buah kopi raranggeuyan

Keun ${ }^{30}$ anu déwék

Ulah pati diheureuyan

10. Kukupu di jero gudang

Ditémbak kena sukuna

Sukur-sukur abdi dipiceun

Sarérét mata aya gantina

11. Samping hideung dina bilik

Kumaha nuhurkeunana

Abdi nineung ka nu balik

Kumaha nutukeunana ${ }^{32}$

12. Kacapi asak ti peuting

Ti beurang didongdo-dongdo ${ }^{34}$
Oh, mother is sick from worrying [about]

The charm of love cast by someone yesterday

How about the flute, how about the flute?

The flute is just out of tune

What about me, what about me?

I am just confused

[See for this stanza that is well-known in Sunda also Van Zanten 1989: 105.]

People say there are many bends in the road

The woven checkered sarong has become wet by the rain

Sister, come here

I am really crazy about you

Leaning backward and slanting

The coffee fruits hang in clusters

Let it not be me,

Let us not harass [the women].

[A similar text is frequently used in the

Cianjuran song Dengkleung.]

The butterfly in the storeroom

It is shot and its feet are wounded

I am very happy to have been turned down

At a single glance there is a replacement

The black sarong on the mat ${ }^{31}$

How do you let it dry?

I am longing for the person who went home

How will the rice be pounded? ${ }^{33}$

The kacapi fruit is ripe in the evening

In the morning it falls down

\footnotetext{
$29=$ Dengkleung, dengklang

$30=(m)$ ingkeun

31 bilik = mat or wall made from woven strips of bamboo.

$32 \quad$ Nutukenana?

33 Possibly this should be taken to be a metaphor for sexual intercourse

34 This is the Baduy word for didongdon-dongdon
} 
Lalaki kasép ti peuting

Ti beurang pangangon kebo

13. Ku naon gaak tanggelak

Teu dibéré pentil ganas

$\mathrm{Ku}$ naon nayaga teu senggak

Ku lantaran teu dibéré cai panas

14. Saha itu numentang payung

Sakieu panas poéna

Ka mana urang menta tulung

Sakieu panas haténa

15. Ka Baros jalan ka Lémbang

Mésér kupat dikincaan

Sanaos urang kagémbang

Ulah lepat kacintaan

16. Moal pati-pati gaplék

Mun lain jeung solontrongan

Moal pati-pati daék

Mun lain kapopotongan

2012-13 Collection Kaduketug

[Written down by village secretary

Sapin, from recitation by young

men at the house of the jaro

pamaréntah in Kaduketug, 22

March 2003]

1. Kaso pondok kaso panjang

Kaso ngaroyom ka jalan
A man looking handsome during the evening

May look after the buffalos during the day ${ }^{35}$

Why does the gaak bird quack?

It has not been given a small pineapple

Why do the gamelan musicians not shout encouragements?

Because they have not been given a hot drink (tea).

Who is holding the umbrella

On such a hot day?

Where do I ask for help

When my heart is so jealous?

To Baros and the road to Lembang

Buy a packet ${ }^{36}$ of cooked rice with fluid palm sugar

Although we are distracted

Do not forget the one you love

[Compare Gunjaér Mundur, stanza 11 and

Collection Cibéo, stanza 4]

Those are not really sliced and dried pieces of cassava

Do not hasten yourself

If you really don't want it

Let it not come to a break [with your partner]
Short grass, long grass

The grass bends over towards the road

35 Baduy are not allowed to have buffalos.

$3^{6}$ Kupat, rice, packed and cooked in a small bag woven from coconut palm leaf 
Sono mondok sono nganjang

Sono patepang di jalan

2. Kini-kini kuang-kuang

Katinggang tali jambatan

Nini teu daék hudang

Dibekok cacalangapan

3. Gedang gandul (2x)

Dieunteupan bébék goak

Bikang gundul (2x)

Dideukeutan bau puak

4. Ngala kacang diguntingan

Di wadahan ka boboko

$\mathrm{Nu}$ nganjang gugulintingan

Sihoréng teu boga rokok

5. Sok hayang ka petis moris

Teu bisa masianana

Sok hayang ka bikang geulis

Teu bisa ngasihanana

6. Salawé sok dua puluh lima

Meuli hiris ti Malingping

Awéwé jaman ayeuna

Hayang geulis dikeriting

7. Cucurut anakna beurit

Tiang ranjang galih laban

Gara surup geura burit

Hayang nganjang ka Cisaban

8. Daun salam daun salasih

Jambu médé diduakeun

Hatur salam terima kasih

Jeung bébéné siling doakeun

9. Kanyéré di pasir pari

Leubeut buah kembang jéngkol
I long to stay for the night, I long to visit [you]

I long to meet [you] on the road

The larva of the large dragon-fly, the

water-insect

Had come down on the rope of the bridge

Grandmother does not want to get up

She is farting incessantly

The pawpaw is hanging

The sitting duck quacks

The woman has a bald head

If you get near she stinks from farting

Take the beans and cut them in parts

From the box to the basket

The one who pays a visit and tumbles down

Lo and behold, has no cigarettes!

I want shrip paste [of the Moris brand?]

It cannot be cut in parts

I want the beautiful woman

I cannot arouse her love

Salawé means twenty-five

To buy hiris beans in Malingping

The girls of today

Want to look nice by curling their hair

The young of the stinking shrew, the mouse's young

The pole of the couch, the kernel of the laban tree

Because the sun sets and it will soon get dark

I want to pay a visit in Cisaban

The salam leaves, the basilicum leaves

The cashew nut is split in two halves

I greet and thank

I pray that it will continue with my love

The kanyéré tree at the thornback fishmarket Many fruits on the jéngkol tree 
Awéwé jaman kiwari

Gedé puak beuki ngompol

10. Tonggérét owét-owétan

Jamparing pegat talina

Awéwé sésérédétan

Katémbong liang ceulina

11. Ngagogodoh cau emas

Nganyam bilik pileuiteun

Ulah sok bogoh ka sémah

Ari balik sok leungiteun

12. Kacapi ukir-ukiran

Ngarambat kana jandéla

Lalaki euweuh pikiran

Teu nyaho ka bikang héwa

13. Boboko ragrag ti para

Angin barat katimurkeun

Kabogoh ulah katara

Kudu bisa nyalimurkeun

14. Minyak aing minyak watu

Diwadahan ku baralak

Paingan aing teu laku

Horéng doang bayawak
Nowadays the women

Fart a lot and wet the bed even more

The cicada makes its sound [sings] ${ }^{37}$

The arrow broke the string

The woman feels a continuous longing

The hole in her ear becomes manifest

The golden banana is being baked

To twine bamboo strips to be used for the rice shed

Do not fall in love with your guest

When she/he goes home you will miss her/him

The zither is ornamented with woodcarvings

It climbs against the window

A man who does not think

Does not realise that women may not like him

[Compare 1992-1 Ceuk Arileu, stanza 2]

The rice container falls from the attic

The west wind is veering to the east

Let your love not be seen

You should be able to mask it

My oil, sesami oil (wijén)

Is placed in dry coco-palm leaf

Why is it that I am not popular?

Well, I look like a crocodile ${ }^{38}$

Stanza 14 was obtained from the jaro

pamaréntah Daénah in his house, 20 March

2003 (A2003-1: 22).

\section{3-14 Collection Hamdan}

(Singing solo and reciting the text

by kacapi player Hamdan on MD

2003-12, 15:22 in Kaduketug, 5 April

2003.)

37 Eringa (1984) and KUBS (1976) give for 'oé: the sound made by a buffalo, but Hamdan explained [on MD 2003-12, 10:49] that the Baduy use it for the sound of the cicada.

38 Bayawak also means 'sponger'. 
1. Kikinciran dina leuwi

Kokojayan dina muhara

Dipikiran leuwih nyeri

Bubuhan mah bapa budak sangsara It cannot be avoided that the father of my

2. Kuma suling (2x)

Mun suling sarilung baé

Kuma kuring (2x)

Mun kuring mah bapa baringun baé As for us sir, we are only confused

3. Daék kuring ngadu manuk

Lamun sarua matana

Daék kuring adu imut

Lamun samua cintana

4. Hujan deui (2x)

Hujan géh hujan pamarat

Bujang deui (2x)

Bujang géh bujang madarat ${ }^{39}$

\section{3-15 Collection Cibéo}

This collection was obtained from

someone living in Cibéo, probably

the Inner Baduy who accompanied Karamaén on 5 April 2003. On that date Karamaén was interviewed and played kacapi on MD 2003-13.

1. Saninten buah saninten

Diteundeu di parapatan

Hapunten abdi hapunten

Bilih aya kelepatan children suffers

[Compare 2003-12 Collection Ina from Pal Opat, stanza 7]

The mills in the deep part of the river

To swim in the delta of the river

Worrying will hurt more

How about the flutes, how about the flutes?

As for the flutes, these are just out of tune

What about us, what about us?

I would like to have a competition between the birds

To see whether they have the same eyes

I want to smile

When we are both in love

Rain again, rain again

This rain also permeates everything

This boy again, this boy again

This boy is also a very poor boy
The chestnut tree, the chestnut

Laid down at the cross-road

I beg your pardon $(2 \mathrm{x})$

If there were mistakes

[This could be sung at the end of a person's

performance] 
2. Anak ciung dina pisitan

Buahna aratah baé

Dicium ku nu kumisan

Sabulan karasa baé

3. Seungit panggang walik

Ngala supa diwalagar

Pamajikan jurung balik

Ménta supa pamaraban ${ }^{41}$

4. Ka Baros jalan ka Lembang

Mésér kupat dikincaan

Sanaos urang palepat

Ulah poho kacintaan

5. Kutak koték dina lincar

Dina catang kimarémé

Geura gedé geura pintar

Geura kaparaban bébéné

6. Kopo kondang kopo kondang

Kopo di bangbara leuweung

Bodo bongan (2x)

Bodo disangsara deungeun

\section{Cau raja turun jantung}

Jadikeun sahoya baé

Euweuh bagja ulah pundung

Jadikeun baraya baé

8. Sireum kilang dina layeus

Paéhna patunjang-tunjang

Ngomong urang geus-anggeus

Kiwari papulang-pulang
The starling young in the pisitan ${ }^{40}$ tree

Which fruits are really fresh

Kissed by someone with a beard

Will be felt for one month

The nice smell of a roasted walik bird

Take the burned mushrooms

The wife is sent home

She asked for mushrooms to eat

To Baros and the road to Lembang

Buy a package of coconut leaves with fluid palm sugar

Although we do forget

Do not forget about love

[Compare 2003-Gunjaér Mundur, stanza 10;

2003-12 Collection Ina, stanza 15]

Knocking on the skirting-board

On the trunk of the kimarémé tree

Growing-up fast [is] clever fast

You will soon have to care for your wife

The kopo [and?] kondang trees (2x)

The kopo tree near the bumble bee from the forest

This stupidity is your own mistake!

Because of stupidity you will be hurt by strangers

The bunch of raja bananas falls

It will only become a hand

If you are not prosperous, do not be angry

Just make it a friendly relationship

The ant, although starving,

Dies with its feet against each other

Yesterday we talked

Today we end our marriage

40 Kind of $d u k u$, fruit tree (Lansium domesticum).

$41 \quad$ Parab, food (Eringa 1984). 
9. Buah ceri" ${ }^{42}$ lebet teuing

Sapasi dibawa naék

Ulah seuri deukeut teuing

Bisi abdi majar ${ }^{43}$ daék

10. Meuli kaos jeung tudung laken

Aya kadal ulah gagabrétan ${ }^{44}$

Sinaos ${ }^{45}$ lamun ka batur

Kami sadar ka pangéran
The most inner part of the cherry

One slice is taken and lifted

Don't smile from so near

It may be that I want [you]

To buy a T-shirt and a hat made of cloth

[If] there is a lizard, do not [go on a razzle/get frightened?]

But then again, when we go to someone

We must be aware of god

42 Ceri not in Eringa 1984 or KUBS 1976.

43 Abdi majar translated as 'I'. Eringa (1984): si majar ka ngaing (in pantun stories): my person, I; KUBS (1976): majar[pajar], it is said, reported.

44 Gabrét, not in Eringa 1984, KUBS 1976; Eringa gives ngabrét to jump and abrét-abrétan in the figurative sense as 'to go on a spree/razzle.'

45 Presumably sanaos = sanajan, although, even though. 